\title{
How to define ecology on the basis of its current understanding?
}

\author{
Peter Urban $^{1 *}$, Peter Sabo ${ }^{1}, J_{a n}$ Plesník $^{2}$ \\ ${ }^{1}$ Faculty of Natural Science, Matej Bel University, Tajovského 40, \\ 97401 Banská Bystrica, Slovakia \\ ${ }^{2}$ Nature Conservation Agency of the Czech Republic, Kaplanova 1931/1, \\ 14800 Prague 11 - Chodov, Czech Republic
}

\begin{abstract}
Urban P., Sabo, P., Plesník, J., 2021. How to define ecology on the basis of its current understanding? Folia Oecologica, 48 (1): 1-8.

The frequently used term ecology is currently interpreted in various ways. This scientific discipline has undergone relatively dynamic development since its inception, and its character is still widening and changing. Therefore, in this contribution we attempt to briefly summarize the subject and contents of current ecology, as well as to propose its more systemic and comprehensive definition. We try to enhance its present definitions especially by putting emphasis on the dynamics of nature (the dynamics of natural processes). We define current ecology as the science dealing with the structure, dynamics and functions of nature including evolution, where structure involves the distribution and abundance of individual organisms, habitats and ecosystems; dynamics include all the aspects of their life trajectories and cycles, including growth, development, reproduction or renewal, interactions and their changes, the cycling of matter, flows of energy and information and their transformations; and functions involve the properties, traits and niches of individual organisms and species in an ecosystem, as well as the properties and niches of ecosystems in the landscape, ecoregion or in the whole Earth system.
\end{abstract}

\section{Keywords}

dynamics of natural processes, ecological integrity, ecology, ecosystem structure, functions of nature

\section{Introduction}

At present, the term ecology is used much more frequently (both in scientific circles and in the general public) than at any time in the past. Not only have sophisticated analyses and abstract mathematical theories rapidly accrued, but also useful practical outputs. However, this term is often interpreted incorrectly, especially by the general public and in the media. It branches off from its original meaning and is merged with wider environmental issues (especially with environmental science) and with environmental management and advocacy (especially with environmental activism, which in connection with environmental philosophy has grown into modern environmentalism, a public movement with its own ideology and policy), or even with various other interests and ideologies. This process has been apparent particularly since the 1960s.

Ecology is thus used as an ideological abracadabra, which contributes to the merging of various ideas and is ungenial to ecology itself (SKLENIČKA, 2011; SUCHOMEL et al., 2014). But ecology is a regular scientific discipline, one of the central branches of biology (together with evolutionary and conservation biology, they are sister scientific disciplines on living nature) and overlaps with many others, especially with genetics, evolutionary theory, ethology and physiology (BEGON et al., 1996). Therefore, despite the fact that its outputs have wide practical uses, it is necessary to apprehend it in this meaning and to consistently disengage it from other semantic tendencies, just as it is necessary to distinguish between an ecologist, an

*Corresponding author:

e-mail: urban.lutra@gmail.com

sciendo

(C) 2021 Authors. This is an open access article under the CC BY-NC-ND license (http://creativecommons.org/licenses/by-nc-nd/4.0/) 
environmentalist and an environmental activist. However, we should mention that there are authors attempting to synthesize environmental science and ecology, at least emphasizing their mutual overlap (FrEEDMAN, 1995; YADAV and MisHRA, 2004).

On the other hand, it is also logical that this scientific discipline itself has been displaying a high boom in dynamics, which is also reflected in its various definitions. Currently, there are many approaches emphasizing various aspects of ecology, but for the most part they are not very complex. In this contribution we try to summarize the subject and contents of current ecology as a modern and highly integrative scientific discipline. Consequently, we try to propose its more systemic and comprehensive definition, which should be more in line with current scientific knowledge.

\section{A short look back}

The term ecology has the same roots as the word economy (from the Greek "oikos" - household, home, place for life); therefore, with a certain simplification, we can say that it deals with the economy of nature (RICKLEFS and RELYEA, 2014). This necessarily includes the study of organisms, their distribution, mutual relations and interactions, as well as their requirements for and interactions with their place for life - the environment. It is not surprising that Haeckel's original definition (based on broad morphological studies of organisms during their ontogenesis) dealt with the relations of organisms and their environment and with their mutual relations (HAECKEL, 1866). Darwin denoted these relations as the conditions of organisms' struggle for existence; however, this is far from the much broader substance of ecology, which includes the understanding of comprehensive processes taking place in nature. (All the ecological processes emerge as concatenations of numerous and diverse interactions of the individual elements of ecological systems.)

Ecology was initially perceived as an inseparable and fully integrated part of biology. Roughly in the 1920s the character of this discipline began to change and to become an independent and authentic scientific discipline. In the process it became clear that ecology is a science in which all the features delineated by classical physics cannot be applied (KovÁř́, 2014).

Among the first scientists who contributed to the development of ecology were geographers. The most prominent among them was the geographer, geologist, botanist, meteorologist, explorer and top polyhistor Alexander von Humboldt (1769-1859), who in his magnificent masterpiece (divided into many volumes) Voyage aux régions équinoxiales du Nouveau Continent fait dans les annés 1799-1804 par Alexander de Humboldt et Aimé Bonpland (Personal Narrative of Travels to the Equinoctial Regions of the New Continent during the years 1799-1804) described organisms and ecological factors in the tropical regions of Latin America.

Among his most considerable productions, the book Cosmos, a marvellous "portrait of nature", should be mentioned. It expressed Humboldt's deep awe before the diversity and at the same time the interconnectedness and harmony of the natural world, as well as his search for universal underlying and unifying principles and patterns hidden behind this diversity and seeming chaos. The dynamics of Cosmos also includes a widening and deepening of the perception of nature by man, which has a great positive influence on him (WALLS, 2009). Humboldt intensively perceived in particular the common genesis of organisms, the climate and the Earth's crust, and his studies became the basis of a new scientific discipline, biogeography (Sмiтh, 1996; Sмiтн and Sмiтh, 2014).

The development of ecology was influenced also by many prominent botanists. For example, Danish botanist Johannes Warming (1841-1924) strived to unite various subdisciplines of botany, emphasizing the impacts of environmental factors on vegetation composition (SMITH, 1996). Plants's life forms from another Danish botanist, Christen Christensen Raunkiær, are still used to characterize plant communities (RAUNKIæR, 1934). Swiss botanist Josias Braun-Blanquet (1884-1980) also proposed a widely applied vegetation classification according to the species composition in communities and an evaluation of the abundance of individual species in them (Braun-Blanquet, 1932). American botanists Henry Chandler Cowles (1869-1939) and Frederic Clements (1874-1945) were the first to study vegetation succession. For Clements biocoenosis was no more a set of intact elements, but a network of mutually interacting species which together form a kind of a ,superorganism“. Although the notion of a superorganism was mostly rejected, Clements's theory of succession as consequent developmental changes of vegetation leading to a climax community is, with some improvements, still well recognized today (CLEMENTS, 1916).

The arrival of a new phase of ecological thinking (the so-called ,new ecology") coincided with a widening of the research from plants to also embrace animals. Emphasis was placed on cooperation and social integration, which is facilitated mainly through mutually advantageous relations between producers and consumers.

German limnologist, freshwater biologist and ecologist (with a strong interest in aquatic insects) August Friedrich Thienemann (1882-1960) introduced the concept of trophic levels and formulated three fundamental biocenotic principles (ThiENEMANN, 1921, 1925, 1926). His lake research led to the first typology of European lakes based on their biological productivity (THIENEMANN, 1931).

One of the founders of the new ecology, English biologist (zoologist) Charles Sutherland Elton (19001991), emphasized the study of biotic factors' influence on organisms and their populations (more precisely with representative samples of these populations). He elaborated the trophic chain and food web issues as an important, integrating mechanism within communities (ElTon, 1927) and also paid attention to quantitative aspects (changes in the occurrence and sizes of populations in a given area, ELTON, 1935). His transition from a descriptive methodology (in which complexities often constrained scientists from generalizations) to 
a functional methodology, which describes relations, striving to analyse universal causality through key patterns and attributes common for distinctive animal taxa or even for distinctive geographical areas, was also important (PIVNIČKA, 1986). He aimed at paying attention to existing ecological knowledge that would enable the building of a new theoretical model of an ecological community. Therefore, Elton aimed at the structure and functions of a community, and to a lesser extent also its dynamics (KeLler, 1997). He was the first to define an ecological niche as a basic functional role, the position of an organism in a community, and he also dealt with population cycles of wild animals and with invasive alien species (ELTON, 1958).

The works of American mathematician, physical chemist and statistician Alfred James Lotka (1880-1949) and Italian mathematician Vita Volterra (1860-1940) were rather influential in the development of ecology and general biology in the 1920s. These two scientists, independently of one another, proposed sets of differential equations describing logistic growth in populations, applicable to the study of competitive and predator-prey relations between organisms (the Lotka-Volterra model of the logistic growth of two competing species and the model of predation, LOTKA, 1925; VoLTERRA, 1926a, b). The model of population dynamics describing a rise in the number of predators depending on the numbers of their prey is among the first attempts at mathematical clarification of the mechanisms controlling and enhancing species coexistence.

Oxford botanist Arthur George Tansley (18711955), who pragmatically strived to introduce quantitative assessments into ecology and to get rid of all its romantic depositions, became the leading personality of the new ecology. The basis for this was his concept of the ecosystem, which he proposed and introduced into biology in 1935. Tansley defined an ecosystem as a basic ecological unit, in which a biological community is integrated with its physical environment (TANSLEY, 1935).

The authors of another widely used definition were Australian zoologist, entomologist and animal ecologist Herbert George Andrewartha (1907-1992) and his disciple, Australian population ecologist Louis Charles Birch (1918-2009), who considered especially the study of distribution and abundance of organisms as the subject of ecology. Their publication The Distribution and Abundance of Animals (ANDREWARTHA and BIRCH, 1954) caused a significant furore. They questioned, inter alia, whether there really is "equilibrium in nature". They also introduced the concept of a "relative shortage", by means of which they explained locust population dynamics, and they pointed to the fact that local populations of insects are often ephemeral, and oscillations and consequently also fluctuations in their numbers do not express the dependence of their density on control, but rather reflect the influence of weather.

They called attention to the phenomenon that what seems to be one population (at first glance), may in fact be a whole series of local populations interconnected by migrations and movements of various intensity. They clarified the fact that local extinction is a common phenomenon in a population, while global extinction is avoided due to the fact that one population goes extinct and others arise. They stated that places which are occupied today may not be occupied tomorrow and again occupied in a week, or within a year, respectively. However, they were criticised for not formulating their population theory in a mathematical language. The classical metapopulation model (e.g. LeVIns 1969, HANSKI and GilPin, 1997) and source-sink dynamics were linked to their direction (Pulliam 1988).

In 1957, British-American zoologist, ecologist and limnologist George “G” Evelyn Hutchinson (19031991) formulated the first complex definition of the ecological niche. In his mathematical definition, a niche is represented by a set of values of ecological factors, as points in an " $n$-dimensional hypervolume", in which each factor represents one dimension. An ecological niche is a part of the hypervolume, in which certain ranges of the values of ecological factors provide suitable conditions for the survival and reproduction of a species (HuTCHINSON, 1957). This means that organisms did not inhabit the whole ecological hypervolume, but just the suitable part of it, bounded by the zones of the organism's tolerance towards the individual ecological factors.

A significant shift was achieved by a prominent American ecologist from the first half of the 20th century, Eugene Pleasants Odum (1913-2002), who considered ecology as the study of the structure and functions of nature, i.e. the study of the ecology of ecosystems (ODum, 1971), or more precisely the organization of all hierarchically higher living systems, starting from the organism (ODUM, 1977). He was among the first to point out that the hierarchical organization of nature, from genes, through organisms, up to biological communities, which was also enhanced by their abiotic environment, form an ecosystem (ODum, 1953). Therefore, the approach of E. P. Odum and his brother Howard Thomas Odum (1924-2002) is sometimes called "cybernetic ecology" (PRINGLE, 2019) (in particular, H.T. Odum introduced the ideas of general systems theory and thermodynamics to ecology) Odum's suggestion that ecology is a science studying the structure and functions of nature was further developed by the American ecologist Robert Leo Smith: "structure includes the distribution and abundance of organisms as influenced by the biotic and abiotic elements of environment; and function includes all aspects of the growth and interaction of populations, including competition, predation, parasitism, mutualism, and transfers of nutrients and energy among them" (Sмiтн, 1996; Sмiтн and SмIтн, 2014).

In the methodological approach of the Odum brothers, modern-thinking ecologists have found a suitable way of holistic expression of the organization of living nature (its structures and functions), manifested in many dimensions and complexities (Jeník, 2002). The Odum brothers also defined the "emergent properties" of an ecological system (differing from cumulative properties), which always emerge on a new hierarchical level of organisms's organization (ODUM, 1977). 
Canadian zoologist and ecologist Charles Joseph Krebs (*1936), apart from the distribution and relations between organisms, also emphasizes the flows and transformations of matter in ecosystems. He defined ecology as a scientific study "of the processes regulating the distribution and abundance of organisms and their mutual relations and the study of how these organisms facilitate transport and transformation of energy and matter in the biosphere, especially the study of the structure and function of ecosystems" (KREBS, 1972). According to British biologist and ecologist Michael E. "Mike" Begon (*1951), ecology is the understanding of the processes and structures in living nature (BEGON et al., 1996, 2006).

Current understanding of ecology - emphasis on the dynamics of natural processes

Today, many studies emphasize only the high dynamics of natural processes. Even in the recent past the premises of ecology included the assumption that natural systems exist or at least head for a certain "equilibrium" and only rarely are disturbed by the impacts from the outer environment (PLESNí, 2010). Therefore, the logical aim of ecosystem management was to maintain their natural "ecological equilibrium", measured and quantified by means of the indicators of ecological stability. Ecological stability (in the sense of homeostasis) means that an ecosystem, a landscape or an ecoregion exists in a state of equilibrium or in cyclically repeating sequences of several quasiequilibrium states, while the basic mechanism keeping ecosystems in such an equilibrium is a negative feedback.

However, according to many paleontological studies, literature reviews and meta-analyses, the "equilibrium state in an ecosystem is rather rare" (ROHDE, 2006): thus, stable, unchanging ecosystems practically do not exist in nature (BotKIN, 2016). Not only organisms, but also ecological systems are characterized by their high dynamics, their movement along their life trajectories (lifelines, Rose, 1998) or eventually complex life cycles (e.g. various phases of the forest cycle), an integral part of which are changes in their material, energetic and information balance - from the point of view of inputs, flows through the system, their transformations, and subsequently outputs. Apart from this, the more detailed analysis has revealed that ecological equilibrium is exactly the consequence of the relatively high natural dynamics of the elements at lower hierarchical levels.

Therefore, the paradigm of ecology is changing, and instead of stability, emphasis is placed on the high dynamics and complexity of ecological systems, leading to their nonlinear behaviour (ProulX, 2007). The high dynamics of nature grasps well the metaphor of the "flowing mosaic of habitats", which considers both deterministic and stochastic processes (PLESNí, 2010). The species in communities and ecosystems are interconnected by diverse numerous "interactions of a variable strength, which take part in their evolution" (we should note that not only elements - species, but also their interactions develop during biological evolution). The system analysis is applied not just in population and ecosystem ecology, but also in evolutionary and behavioral ecology (FISHER and PruitT, 2020).
Ecological equilibrium in this new systemic view means that ecosystems develop on the basis of spontaneous self-organization processes and their achieved organization (and order) is maintained by spontaneous self-regulation processes. Therefore, the new aim of ecosystem management is to improve and maintain, or recover, their ecological integrity, which is the indicator of the health of the respective ecological and biological system (Woodley, 2010; SABO et al., 2017, 2020; Plesní, 2019). The tools to achieve this should be based on strengthening the natural structure of microbial, fungal, plant and animal communities, as well as the natural dynamics of hierarchically lower life-supporting biological and ecological processes, as these dynamics are a precondition of the integrity of higher levels (HoLLING, 2001).

Among the new trends in ecology, especially in system and ecosystem ecology, is also the dynamic nonequilibrium paradigm of an ecosystem, which even prevails during its life cycle. This is due to the fact that ecosystems are not closed systems isolated from their environment; on the contrary, they intensively exchange matter, energy and information with this environment, which is projected into the high dynamics of the processes in a system of complex autopoietic networks (NARUSE and IBA, 2008). These high dynamics are conditioned and influenced by the synergic activity of various and numerous internal and external interactions and ecological factors; therefore, their behaviour is strongly non-linear, thus it is rather hard to predict and project ecosystem development (PARROTT, 2010).

Therefore, the state of ecosystem equilibrium is rather rare and limited in time (PLESNíK, 2010). Furthermore, ecosystem equilibrium is a dynamic sequence of quasiequilibria states. This dynamics and the trend of increased ecosystem organization complexity can be observed during ecological succession, as well as during study of biological and thus also ecosystem evolution. An increase in this complexity during evolution is most outstanding in long-term stable environments (ADAMI et al., 2000). In this non-equilibrium perspective of an ecosystem, the essence of homeostasis of the whole is the already mentioned continual high dynamics of its components and the almost continual changes in the flows of matter, energy and information, e.g. in the case of a forest ecosystem visible in small forest patches (URBAN et al., 2018). Ecosystem dynamics is linked with well recognizable patterns of the ecosystem's successional and evolutionary development, despite the fact that not only deterministic, but also stochastic (and even chaotic) processes occur there.

Important ecological rules applied in the mentioned dynamics are e.g. assembly rules, which determine the selection of the most suitable combination of species and their genomes at each point of the life cycle of a perpetually developing ecosystem. This led Danish chemist and ecologist Sven Erik Jørgensen to formulate "the ecological law of thermodynamics", which connects the selection of optimal species combination with an inherent system heading towards higher complexity to conserve as much high quality energy (exergy) as possible (JørGENSEN, 2012). This is also partially demonstrated 
by the evolutionary convergence of ecosystems in a similar environment. It has already been knowledge that ecosystems in the northern and southern hemisphere have (under the same input of solar radiation and similar precipitation) very resembling species composition and level of complexity - based on very similar sets of the available niches, despite the fact that in reality they are occupied by different species (SALTHE, 2005).

The answer to high complexity of perpetually changing and reorganizing ecological systems (including the complexity of their structure and their high and complex dynamics) is the concept of ecological integrity (EI). Integrity expresses the wholeness, completeness and quality of the organization of an ecological system (KAY, 1991, 1993; KAY and SchNEIDER, 1992). While ecological complexity denotes the complex organization of an ecological system, ecological integrity is a measure of its intactness, completeness and authenticity, which at the same time provides its functionality and its resilience and resistance towards external disturbances (SABO et al., 2017). It is the ability of a system to develop and maintain its complex organization (including its structure and function) through original self-organization and selfregulation mechanisms, while safeguarding its original physical structure, species composition, functionality and natural level of complexity. The higher the ecological integrity, the higher then is its vitality and functionality, including its capacity to provide a full range of ecosystem services (DE GROOT et al., 2010), and the higher is its resilience.

It is necessary to realize that ecological complexity (including biodiversity) and ecological integrity are important parts of the natural capital, i.e. the natural basis generating ecosystem services utilized by human societies. As the whole existence and prosperity of a human society is bounded to these services, and therefore to the natural capital, this existence and prosperity definitely depend on maintaining and recovering the original ecological complexity and integrity of the ecological systems at various hierarchical levels. It is not enough to conserve and manage organisms and ecosystems as natural objects; it is also necessary to maintain or recover diverse and numerous interactions and processes as crucial strands in the autopoietic networks of life.

\section{How to define ecology at the present time?}

As results from the previous text, the notion of ecology has recorded an important shift in its content, significance and understanding. Currently it is an independent, complex and diversified scientific discipline that studies the distribution and abundance of organisms and ecosystems, their interactions and processes, including flows and cycles of matter, energy and information, as well as their changes, in order to understand the structures and processes in living nature (StORCH and MinulKa, 2000).

Therefore, we consider it is necessary to enhance the previous definitions, especially the one by Odum, which is widely used, to include the now very important dynamics of nature, as well as its functions (which become ecosystem services, when utilized by human society). This dynamics is expressed in the behaviour of each ecological system, in its life cycle - growth of biomass, successional and evolutionary development - as well as in its disturbances (followed by partial disintegration), but also in its recovery, or more precisely in its innovative reorganization (Gunderson and Holling, 2009; Urban et al., 2018). Our proposal for how to cope with this enhancement in the definition of ecology is as follows:

Current ecology is the science studying the structure, dynamics and functions of nature, whereby

- structure includes the distribution and abundance of organisms, communities and ecosystems;

- dynamics includes all types of their interactions and processes of growth, development and reproduction (or regeneration), as well as all the flows and transformations of matter, energy and information through this structure;

- functions include the properties and niches of organisms in an ecosystem as well as the properties and functional roles of ecosystems in a landscape, ecoregion, biome and in the Earth system.

As can be seen, this proposal does not reject the previously outlined explanations of the term ecology; we have merely tried to unite and to enhance them in order to reflect recent developments in this scientific discipline. Therefore, we do not see a reason to change the classical explanation of a structure, which is a subject of many studies and which we have taken from several authors, mainly from Sмiтh (1996) and Sмiтh and Sмiтh (2014). However, we have enhanced it in the sense that the structure of nature in reality also includes the distribution and abundance of communities and ecosystems in the landscape, or generally, on the Earth's surface.

Taking into account the significance of nature's dynamics and reflecting the non-equilibrium paradigm (and its metaphor of the flowing mosaic of habitats, PLESNÍ, 2010), we have inserted into the main body of the above definition especially the fact that current ecology is a science dealing in a substantial number of studies with the high dynamics of nature. As all the processes are carried out on a physical structure, the dynamics of nature are in this definition strictly separated from the physical structure of nature. As interactions are just the basic units of these dynamics, we have also included the processes of growth, development, reproduction or recovery and their changes. Also reflecting the explanation of this dynamics by KREBS (1972), we have enhanced the traditional explanation of dynamics also by explicitly stating that this includes the cycles of matter, flows of energy and information, as well as their various transformations. Apart from Krebs, we have also added information, in the sense of genetic information, as an important and often underestimated natural resource.

As the third part of this definition we have separated the functions of nature from its structure and dynamics. It is true that the functions are generated by the interplay of the physical structure and processes carried on it, however, many of these functions are emergent ecosystem properties, which cannot be understood just by analyses 
of the individual species, their interactions and individual processes. At the same time, analyses of the niches of individual species in an ecosystem, as well as analyses of the ecological roles of their functional groups (guilds), clearly contribute to this understanding. Within the context of the rapid development of the Earth system science (STEFFEN et al., 2020), we have also stressed the importance of the ecological roles of the individual ecosystem in the landscape and within the Earth system itself.

We consider these three basic dimensions of ecological studies to correspond well to the individual dimensions of ecological complexity and integrity, forming together irreplaceable natural capital. This capital also generates a huge range of ecosystem services utilized by human society, which are substantial conditions of our existence and also of our well-being as well as economic prosperity (MA, 2005; DE Groot et al., 2010; DíAz et al., 2019; IPBES, 2019; UN ENVIRONMENT, 2019; SCBD, 2020).

\section{Conclusions}

This proposed attempt to unify and enhance the various classical definitions of ecology has emerged from our pedagogical practice, especially from teaching several related subjects of ecology, as well as from the ecological monitoring and biodiversity protection, conservation, management and sustainable use, in which this term is analysed from various points of view. Other reasons are pragmatic, as the term ecology, considering its wide applications and use, should be understood in the same way not only among academicians, but also among those in the professional practice and finally, in the wider public, too.

We presuppose that only when the terms are clearly understood, interpreted and shared within the expert community also the decision-makers and the wider public have the chance to adopt them correctly. If we want to avoid misinterpretation of the terms ecology, environmental science, environmental activism or environmentalism in public discourse, it is necessary to clarify these terms as precisely as possible. Thus, our proposal of a new definition of ecology should be understood as an attempt to open a discussion on this issue. We will therefore be grateful for any comments, proposals or criticism.

Finally, we believe that the discussion and clarification of what ecology is and what it is not, leading to a better understanding of this term not only among scientists and professionals but also in decision-making and policy as well as in the general public, is a condition of better protection, conservation, management and sustainable use of nature and its services.

\section{References}

Adami, Ch., Ofria, Ch., Collier, T.C., 2000. Evolution of biological complexity. Proceedings of the National Academy of Sciences of the United States of America, 97 (9): 4463-4468.
Andrewartha, H.G., Birch, L.C., 1954. The distribution and abundance of animals. Chicago: University Chicago Press. 793 p.

Begon M., Harper, J., Townsend, C.R. 1996. Stock Image Ecology: individuals, populations and communities. $3 \mathrm{rd}$ ed. Oxford: Wiley-Blackwell, 1068 p.

Begon, M., Townsend, C. R., Harper, J. L., 2006. Ecology: from individuals to ecosystems. 4th ed. Oxford: WileyBlackwell, $750 \mathrm{p}$.

BotKin, D.B., 2016. 25 myths destroying the environment. What many environmentalists believe and why they are wrong. Guilford, CT: Taylor Trade Publ. 320 p.

Braun-Blanquet, J., 1932. Plant sociology. The study of plant communities. New York and London: McGraw-Hill Book Co. 439 p.

Clements, F.E., 1916. Plant succession, an analysis of the development of vegetation. Carnegie Institution of Washington Publication, 242. Washington, D.C., USA: Carnegie Institution of Washington. 512 p.

Díaz, S., Settele, J., Brondízio, E. S., NGo, H.T., Agard, J., Arneth, A., Balvanera, P., Brauman, K.A., Butchart, S.H.M., Chan, K.M.A., Garibaldi, L.A., ICHII, K., LiU, J., Subramanian, S.M., Midgley, G.F., Miloslavich, P., Molnár, Z., Obura, D., Pfaff, A., Polasky, S., Purvis, A., Razzaque, J., Reyers, B., Chowdhury, R.R., Shin, Y.-J., Visseren-Hamakers, I., Willis, K.J., Zayas, C.N., 2019. Pervasive human-driven decline of life on Earth points to the need for transformative change. Science, 366: eaax3100. doi: 10.1126/science.aax3100.

Elton, C. S., 1927. Animal Ecology. Text-books of animal biology. New York: The MacMillan Company. 207 p. [cit. 28-05-2020]. https://ia700301.us.archive.org/7/ items/animalecology00elto/animalecology00elto.pdf

Elton, Ch.S., 1935. Fluctuations in animal populations. Quarterly Journal of Forestry, 29: 194-198.

ELton, C.S., 1958. The ecology of invasions by animals and plants. London: Methuen. $181 \mathrm{p}$.

Fisher, D.N., PruitT, J.N., 2020. Insight from the study of complex systems for the ecology and evolution of animal populations. Current Zoology, 66: 1-14.

Freedman, B., 1995. Environmental ecology: the effects of pollution, disturbance and other stresses. 2nd ed. San Diego: Academic Press. 606 p.

de Groot, R.S., Alkemade, R., Braat, L., Hein, L., Willemen, L., 2010. Challenges in integrating the concept of ecosystem services and values in landscape planning, management and decision making. Ecological Complexity, 7: 260-272.

Gunderson, L.H., Holling, C.S., 2009. Panarchy: understanding transformations in human and natural systems. Washington: Island Press. $450 \mathrm{p}$.

HaeCKel, E.H.P.A., 1866. Generelle Morphologie der Organismen. Allgemeine Grundzüge der organischen Formen-Wissenschaft, mechanisch begründet durch die von Charles Darwin reformirte Descendenz-Theorie. Vol. I. Allgemeine Anatomie der Organismen. Vol. II. Allgemeine Entwickelungsgeschichte der Organismen. Berlin, Germany: Georg Reimer. $32+574$ p., $140+462$ p.

Hanski, I., Gilpin, M.E. (eds), 1997. Metapopulation biology. Ecology, genetics, and evolution. San Diego: Academic Press. 512 p. + xvi. 
Holling, C.S., 2001. Understanding the complexity of economic, ecological and social systems. Ecosystems, 4: 390-405.

Hutchinson, G.E., 1957. Concluding remarks. Cold Spring Harbor Symposia on Quantitative Biology, 22: 415-427.

IPBES, 2019. Global assessment report on biodiversity and ecosystem services. Bonn: Intergovernmental SciencePolicy Platform on Biodiversity and Ecosystem Service. 1753 p. [cit. 28-05-2020]. https://ipbes.net/globalassessment-report-biodiversity-ecosystem-services.

JENík, J., 2002. Ekosystém: nepominutelné mezioborové paradigma [Ecosystem: indefectible interdisciplinary paradigm]. Vesmir, 81: 332-335. [cit. 28-05-2020]. http:// casopis.vesmir.cz/clanek/ekosystem-nepominutelnemezioborove-paradigma.

JøRGENSEN, S.E., 2012. Introduction to systems ecology. Boca Raton, USA: CRC Press, Taylor \& Francis Group. 320 s.

KAY, J.J., 1991. A non-equilibrium thermodynamic framework for discussing ecosystem integrity. Environmental Management, 15: 483-495.

KAY, J.J., 1993. On the nature of ecological integrity: some closing comments. In Woodley, S., Kay, J., Francis, G.. Ecological integrity and the management of ecosystems. Delray, Florida: St. Lucie Press, p. 210-212.

KaY, J.J., Schneider, E.D., 1992. Thermodynamics and measures of ecological integrity. In McKenzie, D.H., HyatT, D.E., McDonald, V.J. (eds). Ecological indicators. Boston, MA: Springer, 159-182.

Keller, J., 1997. Sociologie a ekologie [Sociology and ecology]. Praha: Sociologické nakladatelství. 232 p.

Kovář, P., 2014. Ekosystémová a krajinná ekologie [Ecosystem and landscape ecology]. Praha: Karolinum. $170 \mathrm{p}$.

KREBS, C.J., 1972. Ecology: the experimental analysis of distribution and abundance. New York: Harper and Row Publishers. 694 p.

Levins, R., 1969. Some demographic and genetic consequences of environmental heterogeneity for biological control. Bulletin of the Entomological Society of America, 15 (3): 237-240.

LotKA, A. J., 1925. Elements of physical biology. Baltimore, MD: Williams and Wilkins Company. $495 \mathrm{p}$.

MA, 2005. Ecosystems and human well-being: synthesis. Washington, D.C.: Island Press. 137 p. + x.

Naruse, M., IBA, T., 2008. Ecosystem as an autopoietic system: considering relationship between ecology and society based on Luhmann's theory. Paper for Fourth Joint JapanNorth America Mathematical Sociology Conference. Keio: Keio University. 14 p. [cit- 2020-05-05]. http://web. sfc.keio.ac.jp/ iba/papers/2008JJNAMS08-ecosystem. pdf

Odum, E.P., 1953. Fundamentals of ecology. Philadelphia and London: W.B. Saunders Company. 384 p.

Odum, E.P., 1971. Fundamentals of ecology. 3rd ed. Philadelphia, Pennsylvania: W.B. Saunders Company. $574 \mathrm{p}$.

Odum, E.P., 1977. The emergence of ecology as a new integrative discipline. Science, 195: 1289-1293.

Parrot, L., 2010. Measuring ecological complexity. Ecological Indicators, 10: 1069-1076.

PIVNičKA, K., 1986. Ekologie [Ecology]. Praha: Univerzita Karlova. 204 p.
PlesNík, J., 2010. Př́roda jako proudící mozaika. Co přinesly novější poznatky ekosystémové ekologie [Nature as a flowing mosaic. What recent knowledge in ecosystem science has revealed]. Ochrana Přirody, 65 (3): 27-30.

Plesník, J., 2019. Biologická rozmanitost z pohledu ochrany prírody [Biological diversity from a point of view of nature conservation]. Živa, 67: cxxi-cxiii.

Pringle, T., 2019. The ecosystem is an apparatus: from machinic ecology to the politics of resilience. In PRINGLE, T., Koch, G., Stiegler, B. Machine. Minneapolis, MN: Univ. Minnesota Press, p. 49-108.

Proulx, R., 2007. Ecological complexity for unifying ecological theory across scales: a field ecologist's perspective. Ecological Complexity, 4 (3): 85-92.

Pulliam, H.R., 1988. Sources, sinks and population regulation. The American Naturalist, 135: 652-661.

RAUNKIæR, C., 1934. The life forms of plants and statistical geography. Oxford: Claredon. $632 \mathrm{p}$.

Ricklefs, R., Relyea, R., 2014. Ecology. The economy of nature.7th ed. New York: W. H. Freeman \& Co., 565 p. + ivl.

Rohde, K., 2006. Nonequilibrium ecology. Cambridge: Cambridge Univ. Press. 236 p.

Rose, S., 1998. Lifelines - biology, freedom, determinism. Middlesex, England: Penguin books. 333 p.

Sabo, P., Turisová, I., Škodová, M., Striežovská, L., SNOPKOvá, Z., 2017. Príspevok k hodnoteniu ekologickej komplexity a integrity ekosystémov [Contribution to evaluation of ecological complexity and integrity of ecosystems]. Quaestiones Rerum Naturalium, 4 (2): 30-105. [cit. 01-06-2020]. http://www.fpv.umb. sk/katedry/katedra-biologie-a-ekologie/veda-a-vyskum/ casopis-quaestiones-rerum-naturalium/archiv/2017-no-2/ prispevok-k-hodnoteniu-ekologickej-komplexity-a-integrityekosystemov.html

Sabo, P., Urban, P., Malina, R., Švajda, J., TuRisová, I., 2020. Úvod do systémovej ekológie I [Introduction to systems ecology I]. Banská Bystrica: Belianum. 286 p.

SALTHE, S.N., 2005. The natural philosophy of ecology: developmental systems ecology. Ecological Complexity, 2: 1 -19 .

SCBD, 2020. Global Biodiversity Outlook 5. Montreal: Secretariat of the Convection on Biological Diversity. $208 \mathrm{p}$.

SkLeniČKA, P., 2011. Pronajatá krajina [Rented landscape]. Praha: Centrum pro krajinu. $144 \mathrm{p}$.

Sмith, R. L., 1996. Ecology and field biology. New York: Harper Collins College Publishers. 740 p.

Sмith, Th.M., Sмith, R.L., 2014. Elements of ecology. 9th ed. U.K.: Pearson Harlow. 704 p.

StefFen, W., Richardson, K., Rockström, J., Schellnhuber, H.J., Dube, O.P., Dutreuil, S., Lenton, T. M., Lubchenco, J., 2020. Perspectives. The emergence and evolution of Earth System Science. Nature Reviews, Earth \& Environment, 1: 54-63. [cit. 01-06-2020]. https://www. nature.com/articles/s43017-019-0005-6.pdf?origin=ppub

Storch, D., Minulka, S., 2000. Úvod do současné ekologie [Introduction to current ecology]. Praha: Portál. $156 \mathrm{p}$.

Suchomel, J., Kulhavý, J., Zejda, J., Plesník, J., Menšík, L., 2014. Ekologie lesnich ekosystémů [Ecology of forest ecosystems]. Brno: Mendelova univerzita v Brně, Lesnická a dřevařská fakulta, 166 p. [cit. 01-06-2020]. 
https://akela.mendelu.cz/ xcepl/inobio/skripta/Skripta Ekologie_lesnich_ekosystemu.pdf

TANSLEY, A.G.. 1935. The use and abuse of vegetational concepts and terms. Ecology, 16 (3): 284-307. [cit. 0601-2020]. http://karljaspers.org/files/tansley.pdf

Thienemann, A., 1921. Seetypen. Die Naturwissenschaften, 18: 643-646.

Thienemann, A., 1925. Die Binnengewässer Mitteleuropas: Eine limnologische Einführung. Stuttgart, Germany: Verlag Schweizerbart. $255 \mathrm{pp}$.

Thienemann, A., 1926. Der Nahrungskreislauf im Wasser. Verhandlungen der Deutschen Zoologischen Gesellschaft, 31: 29-79.

Thienemann, A., 1931. Tropische Seen und Seetypen. Archiv für Hydrobiologie. Supplement, 9: 205-231.

UN ENVIRONMENT, 2019. Global environment outlook-GEO6: healthy planet, healthy people. Cambridge: Cambridge University Press. 745 p.

Urban, P., Sabo, P., Plesník, J., 2018. Non-equilibrium thermodynamics and development cycles of temperate natural forest ecosystems. Folia Oecologica, 45 (2): 61-71.
Volterra, V., 1926a. Variazioni e fluttuazioni del numero di individui in specie animali conviventi [Variations and fluctuations of the number of individuals in animal species living together]. Memorie della R. Academia dei Lincei, sser. 6, Ii 3. Città di Castello: Società anonima tipografica "Leonardo da Vinci". 85 p.

Volterra, V., 1926b. Fluctuations in the abundance of a species considered mathematically. Nature, 118: 558560.

WALLS, L.D., 2009. Introducing Humboldt's cosmos. Minding Nature, August 2009, p. 1-15. [cit. 06-01-2020]. https:// www.humansandnature.org/filebin/pdf/minding_nature/ August_2009_Introducing_Humbolt.pdf

Woodley, S., 2010. Ecological integrity and Canada's national parks. George Wright Forum, 27: 151-160.

Yadav, P. R., Mishra, S. R., 2004. Environmental ecology. New Delhi: Discovery Publ. House. 356 p.

Received June 10, 2020

Accepted November 18, 2020 